Agricultural Journal 7 (3): 180-186, 2012

ISSN: $1816-9155$

C) Medwell Journals, 2012

\title{
Molecular and Serological Studies of Iris Yellow Spot Virus on Onion Plants in Iran
}

\author{
${ }^{1}$ Neda Rafizadeh, ${ }^{1}$ Behrouz Jafarpour, ${ }^{2}$ Mehdi Nasr Isfahani and ${ }^{1}$ Mahrokh Falahati Rastegar \\ ${ }^{1}$ Department of Plant Protection, Ferdowsi University of Mashhad, Iran \\ ${ }^{2}$ Department of Plant Protection, Isfahan Research Center for Agricultural Science, \\ Natural Resources Isfahan, Iran
}

\begin{abstract}
The Iris Yellow Spot Virus (IYSV) is one of the diseases of Iris plants in Iran, occurring annually and causing considerable losses. In this manuscript, the molecular and serological studies of the disease were taken placed for the 1st time in Iran. For this purpose, 435 samples with symptoms of chlorotic, necrotic and diamond shape lesion were collected from onion fields and 142 from ornamental plants. The infected plants were transferred into the laboratory for DAS-ELISA tests and the sap of positive plants inoculated to 4 indicator host plants Nicotiana rustica (with leaf deforming and systemic chlorotic and necrosis), N. benthamiana, N. clevelandii, N. tabacum var. samson (with systemic chlorotic and necrosis) in greenhouse conditions. The inoculated indicator plants tested for DAS-ELISA then sap of positive indicator plants inoculated to 4 onion genotypes, neishabour yellow, neishabour white, dargaz red and isfahan red (Dorche). Also for genetical analysis, the RNAs were extracted by PEG6000 precipitation and RNX ${ }^{\mathrm{TM}}$ (plus) kit. In RT-PCR tests, specific primers designed for nucleoprotein gene amplified 181 and $139 \mathrm{bp}$ fragments. It was found that all of the onion fields were infected with the virus in various degrees, out of which IYSV was detected in 107 samples of onion, 7 samples of chrysanthemum flowers and a sample of Iris flowers.
\end{abstract}

Key words: Iris yellow spot virus, DAS-ELISA, onion, RT-PCR, Iris flowers, Iran

\section{INTRODUCTION}

Iris yellow spot virus was first reported affecting onion inflorescence in Southern Brazil in 1981. Then after the disease was not seen again until 1994. When it was detected in North-Eastern Brazil, the disease was characterized by symptoms of chlorotic and necrotic eye-like or diamond shaped lesions inflorescence (Gent et al., 2006). Cortez et al. (1998) described IYSV in the Netherlands as a new Tospovirus naturally infecting Iris hollandica in the field and leek in the greenhouse. Near the same time, Gera et al. (1998) reported that IYSV on onion in Israel. Kritzman et al. (2000) reported natural IYSV infection of lisianthus (Eustoma russellianum) grown in the field in Israel.

IYSV is now known to occur on onion in the following locations: 1999, India; 2000, Slovenia; 2002, Colorado (USA); 2003, Australia and Italy; 2004, Japan, Georgia (USA), New Mexico (USA) and Washington (USA); 2005, Chile, Peru, Spain, Tunisia, central Oregon (USA) and 2006, Reunion Island, Guatemala, Texas (USA) and New York (USA) (Gent et al., 2006). In 2007, Mumford et al. (2008) reported this virus on E. grandiflorum. Gawande et al. (2010) reported this virus on garlic in India for the 1st time. Ghotbi et al. (2005) reported this virus on Plargonium hortorum, Rosa sp., Cycas sp. and Scindapsus sp. IYSV is one of members of family Bunyaviridae genus Tospovirus. The viruses of this genus have enveloped isometric particles $(80-110 \mathrm{~nm})$ which contain virus-encoded Glycoproteins (G1/G2). The genome of Tospoviruses consists of three ssRNA segments denoted L RNA, M RNA and SRNA. The M RNA encodes the Glycoproteins G1/G2 (Silva et al., 2001). Onion thrips, Thrips tabaci (Order, Thysanoptera, Family, Thripidae) is a worldwide pest of vegetable crops. It ranges from tropical and subtropical areas into the temperate regions, T. tabaci is an important pest of field and greenhouse crops all around the world. It causes damages directly by feeding and indirectly by transmitting Tomato Spotted Wilt Virus (TSWV) but only the larval stage can transmit this virus (Pourian et al., 2009). IYSV is transmitted by thrips in a persistent manner. Once a thrips has acquired the virus, it can transmit the virus for the remainder of its lifetime (Crowe and Pappu, 2005). Viruliferous thrips emigrating from harvested onion fields into nonharvested ones may be increasing the primary spread of IYSV in late-harvested onions. Managing T. tabaci populations before harvest and manipulating the spatial arrangement of fields based on harvest date could mitigate the spread of IYSV (Hsu et al.,

Corresponding Author: Neda Rafizadeh, Department of Plant Protection, Ferdowsi University of Mashhad, Iran 
2010). The disease was characterized by symptoms of chlorotic and necrotic eye-like or diamond shaped lesions on scapes (Pozzer et al., 1994). Symptoms appeared as chlorotic or necrotic, straw-colored to white, dry, elongate or spindle-shaped lesions along the scape with lesions frequently more numerous at mid to lower portions of the scape. In some lesions, an island of green tissue developed in the center of the necrotic area. When lesions became large and numerous, they coalesced often completely girdling the scape. This weakened the scape, causing the seed head to collapse and topple over. Patterns of disease incidence in fields or locations were not apparent, nor was there any association with host genotype or cultural practices. Estimated yield losses in individual fields ranged from insignificant to nearly 60\% (Mohan and Wilson, 1989). Reports of the economic losses caused by IYSV in onion range were from high in Israel and Brazil (Smith et al., 2006) to minimal in the Netherlands (Cortez et al., 1998). Symptoms on leaves that could be confused with those caused by fungal or bacterial diseases. Additionally, the necrotic areas resulting from IYSV infection could be colonized by secondary invaders such as Stemphylium sp. or Alternaria sp., leading to inaccurate diagnosis. (Pappu et al., 2008). The disease like as Cladosporium leaf spot (Evans et al., 2009). Most important of indicator plants for this virus are Nicotiana benthamiana and N. rustica with systemic symptoms (Chatzivassiliou et al., 2000). IYSV does not appear to be seed-borne or seed-transmitted in onion (Bulajic et al., 2009).

\section{MATERIALS AND METHODS}

Sampling: An intensive survey was conducted during 2008-2009 to determine the molecular and serological studies of the IYSV on ornamentals and onion plants. In 2008 , during an initial survey, 435 samples of onion and 142 samples of ornamental plants were collected. Samples of ornamentals comprised of leaves from different parts of each plant exhibited various symptom types suggestive of Tospovirus infection, such as yellow or necrotic spots on leaves and tip necrosis. Symptomless onion leaf and scape samples were collected together with those showing symptoms of elongated, chlorotic, necrotic, oval chlorotic, diamond shape lesion or necrotic lesions. Both fresh and frozen $\left(-80^{\circ} \mathrm{C}\right)$ samples were tested for IYSV presence by Enzyme Linked Immunosorbent Assay (ELISA).

Serological testing: Standard DAS-ELISA was performed. Samples were tested for the presence of IYSV utilizing a Double Antibody Sandwich (DAS)-ELISA Method of (Clark and Adams, 1977) serological reagents against IYSV used was from the DSMZ (Brauncheweig, Germany). Absorbance at $405 \mathrm{~nm}$ was measured with an ELISA microplate reader. Samples were considered positive if the absorbance value was $\geq 2$ times the absorbance of the negative control.

Mechanical inoculation: Nicotiana benthamiana, N. rustica, N. tabacum var. samson and $N$. clevelandii were mechanically inoculated with infected onion sap, using $0.01 \mathrm{M}$ potassium phosphate buffer, $\mathrm{pH} 7.0$, containing $0.2 \%$ sodium sulfite and $0.01 \mathrm{M} 2-$ mercaptoethanol (Mandal et al., 2001). A total of 4 plants of each experimental species were inoculated and the bioassay was repeated three times. After inoculation, the plants were sprayed with distilled water and kept in an insect-proof greenhouse at a temperature of $22-25^{\circ} \mathrm{C}$ and were inspected regularly for symptom development. About 3 weeks after inoculation both symptomatic and asymptomatic plants were assayed by DAS-ELISA to confirm IYSV presence and to detect symptomless infections. Some of the ELISA positive leaves were further tested using Reverse TranscriptionPolymerase Chain Reaction (RT-PCR). Also in order to investigate virus transmission to onion plants, 4 onion genotypes (yellow of Neishabour, red of Dorche Isfahan, red of Dargaz and white of Neishabour) were mechanically inoculated with infected nicotine sap using $0.01 \mathrm{M}$ potassium phosphate buffer, $\mathrm{pH} 7.0$, containing $0.2 \%$ sodium sulfite and $0.01 \mathrm{M}$ 2-mercaptoethanol (Mandal et al., 2001). Total of 4 onion plants of each experimental genotypes were inoculated and the bioassay was repeated 3 times. Plants were kept in an insect-proof greenhouse at a temperature of $22-25^{\circ} \mathrm{C}$ and were inspected regularly for symptom development. Three weeks after inoculation, both symptomatic and asymptomatic plants were assayed by DAS-ELISA to confirm IYSV presence and to detect symptomless infections.

RNA extraction: Viral RNA extraction from systemically infected nicotine and onion plants were performed. Two methods were used:

- Sedimentation with PEG 6000 base on Smith et al. (2006) was done

- Extraction with plus ( $\mathrm{RNX}^{\mathrm{TM}}$ ) mixture used from Cinagen company was done

Electrophoresis of extracted RNA in 1\% agarose gel: In order to investigate of RNA quality $3 \mu \mathrm{L}$ extracted RNA with $1 \mu \mathrm{L}$ of color buffer were subjected to electrophoresis in a $1 \%$ agarose gel, stained with $0.5 \mu \mathrm{g} \mathrm{mL} \mathrm{m}^{-1}$ ethidium bromide and photographed under UV illumination. 
Agric.J., 7 (3): 180-186, 2012

Table 1: Primers used for Iris yellow spot virus detection

\begin{tabular}{lllll}
\hline Primers & Direction & \multicolumn{1}{c}{ Sequence of primers $\left(5^{\prime}-3^{\prime}\right)$} & Location & $(\mathrm{bp})$ \\
IYSV-F1 & Forward & GAGATGTGGATGTGGTGATTG & Coat protein & 139 \\
IYSV-R1 & Reverse & GTCTTGTAAATGCCTGCTCTGT & Coat protein & 181 \\
IYSV-F2 & Forward & TAGGGTGAAACCGTCAGAAA & & \\
IYSV-R1 & Reverse & TGTCTTGTAAATGCCTGCTC & & \\
\hline
\end{tabular}

Table 2: RT-PCR mixture

\begin{tabular}{ll}
\hline Quantity & Material \\
\hline $2.5 \mu \mathrm{L}$ & $10 \times$ Buffer \\
$0.5 \mu \mathrm{L}$ & Dntp \\
$1 \mu \mathrm{L}$ & $\mathrm{MgCL}_{2}$ \\
$0.3 \mu \mathrm{L}$ & Taq DNA polymerase \\
$1 \mu \mathrm{L}$ & Reverse primer \\
$5 \mu \mathrm{L}$ & cDNA \\
$13.7 \mu \mathrm{L}$ & Sterile water \\
\hline
\end{tabular}

Table 3: PCR program

\begin{tabular}{llc}
\hline Cycle no. & Time & Tempreture $\left({ }^{\circ} \mathrm{C}\right)$ \\
\hline Stage $2 \rightarrow 36$ cycle & $3 \mathrm{~min}$ & 94 \\
& $30 \mathrm{sec}$ & 94 \\
& $30 \mathrm{sec}$ & 61 \\
& $20 \mathrm{sec}$ & 72 \\
& $30 \mathrm{sec}$ & 72 \\
$10 \mathrm{~min}$ & 4 \\
\hline
\end{tabular}

Primers: The primers used for the cDNA synthesis were either designed based on S RNA of coat protein gene of IYSV previously reported by Ward et al. (2008). Primers were synthesis by Bioneer Company (Table 1).

Amplification of cDNA with Polymerase Chain Reaction (PCR): First strand cDNA was primed on total plant RNA using specific reverse primers using Accupower TMRT Premix kit (Bioneer Company).

RT-PCR: RT-PCR was carried out with the Accupower TMRT Premix kit (Bioneer Company) according to the manufacturer's instructions. The RT-PCR reaction mixture included mixture included $2.5 \mu \mathrm{L} 10 \times$ Buffer, $0.5 \mu \mathrm{L}$ dntp, $1 \mu \mathrm{L} \mathrm{MgCl}_{2}, 0.3 \mu \mathrm{L}$ Taq DNA Polymerase, $1 \mu \mathrm{L}$ Forward Primer, $1 \mu \mathrm{L}$ Reverse Primer, $5 \mu \mathrm{L}$ cDNA in a final volume of $25 \mu \mathrm{L}$ (Table 2). Cycling conditions were as follows (Table 3).

Agarose gel electrophoresis: Amplified products were analyzed by $1.7 \%$ agarose gel electrophoresis, stained with ethidium bromide and visualized under UV transilluminator.

\section{RESULTS}

Virus symptoms: Onion plants with chlorotic or necrotic and diamond-shaped lesions on leaves and especially on scapes (Fig. 1 and 2) were observed in onion fields. Affected plants were spread across the field with very high disease incidence.

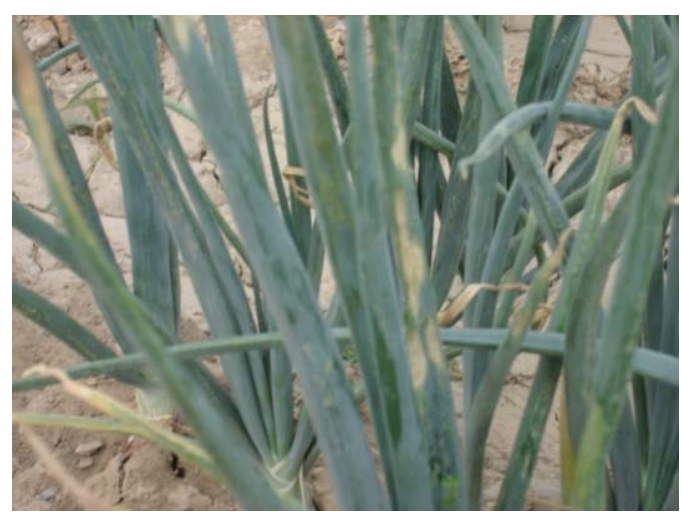

Fig. 1: Symptoms of Iris yellow spot virus in onion field diamond shape lesion (on leaves)

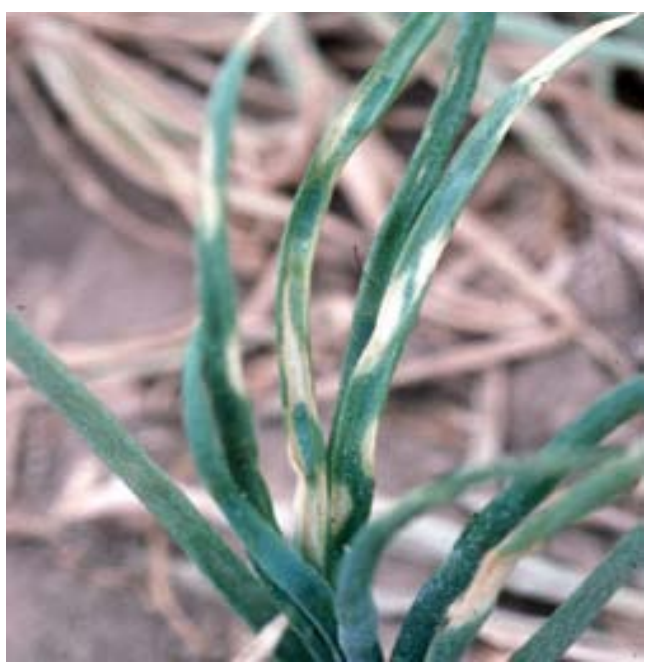

Fig. 2: Symptoms of Iris yellow spot virus in onion field diamond shape lesion (on shapes)

Disease occurrence was associated with a high population of T. tabaci. Also Iris and Chrysanthemum flowers with necrotic lesions on leaves and especially on scapes were observed in greenhouse.

Virus detection and result of ELISA test: Of the 577 samples assayed, 115 reacted positively in DAS-ELISA. 435 samples with symptoms of chlorotic, necrotic and diamond shape lesion were collected from onion fields and 142 from ornamental plants (Rose, Gladiol, Iris, Plargonium, Chrysanthemum, Begonia, Petonia and Carnation). 
Agric.J., 7 (3): 180-186, 2012

\begin{tabular}{lccc}
\multicolumn{4}{l}{ Table 4: Infected plants and percent of infected plants } \\
\hline Plants & Total no. & Infected plants & Infected plants (\%) \\
\hline Onion & 435 & 107 & 24.59 \\
Iris & 8 & 1 & -- \\
Ornamental plants & 142 & - & 5.63 \\
Chrysanthemum & 7 & 7 & --- \\
\hline
\end{tabular}

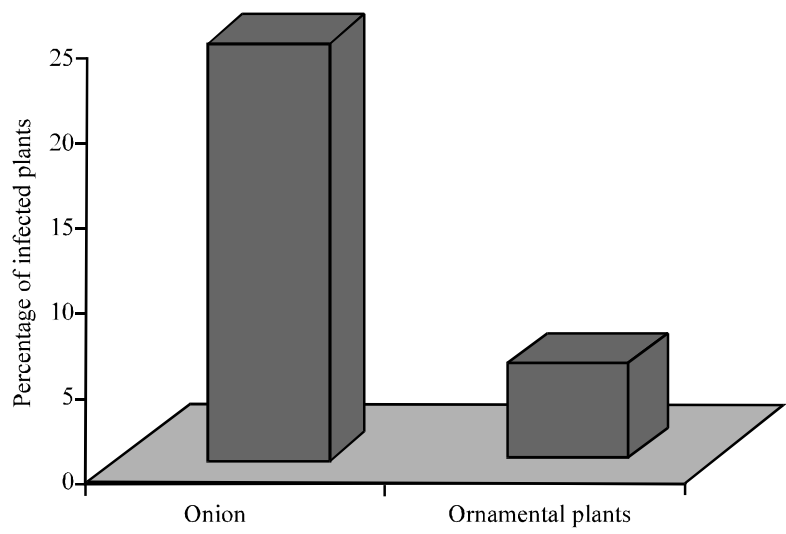

Fig. 3: Percent of infected plants in onion and ornamental plants

IYSV was detected by ELISA in 107 samples of onion (24.59\%), 7 samples of chrysanthemum flowers and a sample of Iris flowers (Table 4 and Fig. 3).

\section{Mechanical incubation}

Mechanical incubation of indicator plants: Different plant species from a botanical family (Nicotiana) were inoculated from selected ELISA-positive plants with Iris yellow spot virus. After inoculation, the plants were sprayed with distilled water and kept in an insect-proof greenhouse at a temperature of $22-25^{\circ} \mathrm{C}$ and were inspected regularly for symptom development. On inoculated leaves of plants symptoms developed within 2 weeks post inoculation. Symptom descriptions on indicator test plants for these viruses are given:

- $\quad$. benthamiana and $N$. clevelandii showed chlorosis and systemic necrosis

- N. tabacum var. samson gave chlorosis and systemic necrosis symptoms

- N. rustica gave leaf deformation and systemic chlorosis and necrosis

About 3 weeks after inoculation, both symptomatic and asymptomatic plants were assayed by DAS-ELISA to confirm IYSV presence and to detect symptomless infections (Table 5 and Fig. 4, 5).

Mechanical incubation of onion genotype: Four onion genotypes (Yellow of Neishabour, Red of Dorche Isfahan,
Table 5: Percent of infected indicator plants

\begin{tabular}{lccc}
\hline Plant cultivar & No. of plants & Infected plants & Infection (\%) \\
\hline Nicoticna tabacum & 15 & 7 & 46.6 \\
var. samson & & & \\
N. rustica & 10 & 4 & 40.0 \\
Nicotiana benthamiana & 13 & 6 & 46.1 \\
Nicotiana clevelandii & 16 & 10 & 62.5 \\
\hline
\end{tabular}
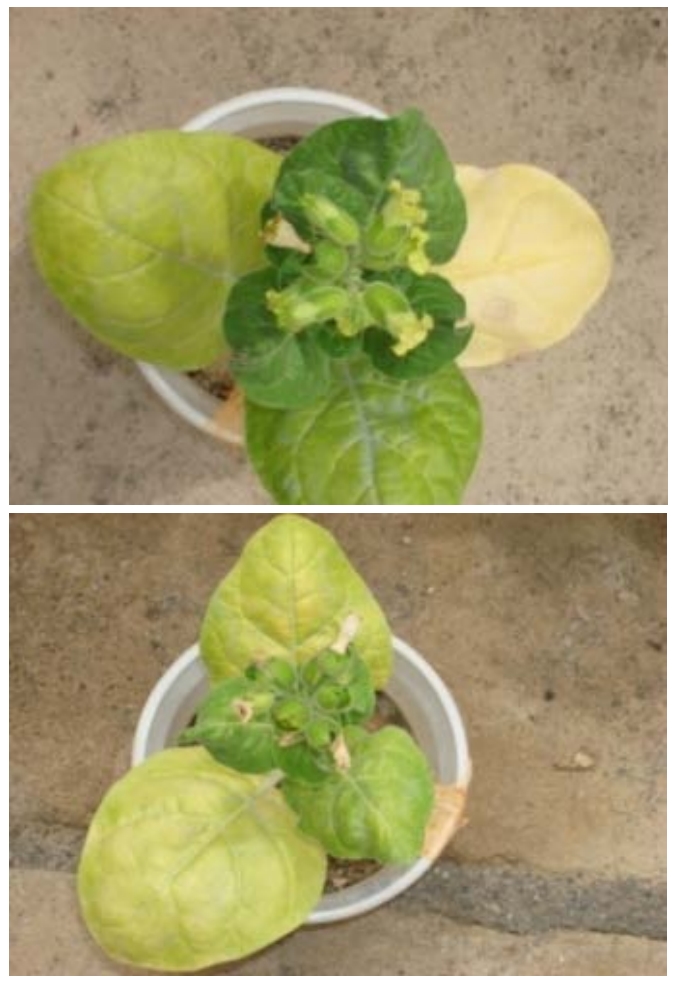

Fig. 4: Symptoms of IYSV in N. rustica deforming leaves, systemic chlorosis and necrosis

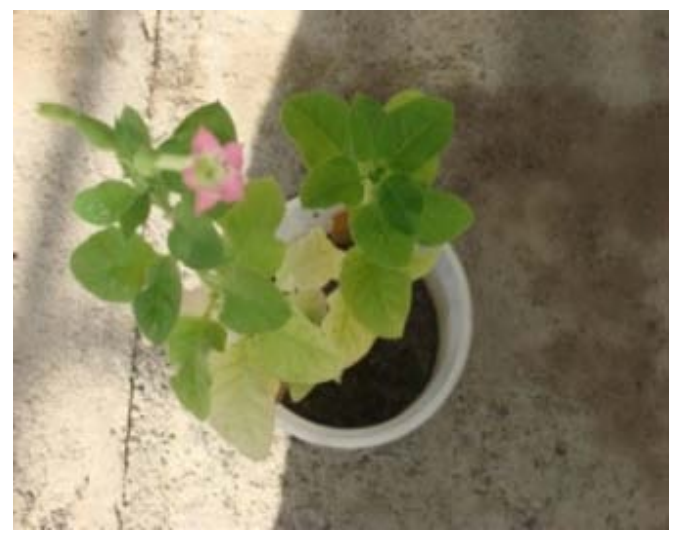

Fig. 5: Symptoms of IYSV in N. clevelandii: Chlorosis and systemic necrosis

Red of Dar gaz and White of Neishabour) were mechanically inoculated with infected nicotine sap. Onion plants were inoculated and were kept in an insect-proof 


\begin{tabular}{lccc} 
Table 6: Results of DAS-ELISA test of cultivars of onion \\
\hline Name of cultivar & No. of plants & Infected plants & Infection (\%) \\
\hline Neishabour yellow & 15 & 7 & 46.6 \\
Isfahan red (Dorche) & 12 & 6 & 50.0 \\
Dargaz red & 13 & 3 & 23.0 \\
Neishabour white & 17 & 1 & 5.8 \\
\hline
\end{tabular}

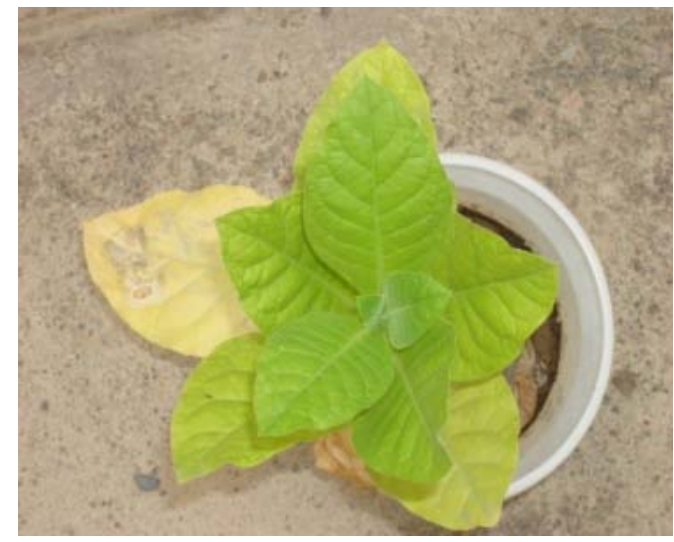

Fig. 6: Symptoms of IYSV in N. tabaccum var. samson: Chlorosis and sustemic necrosis

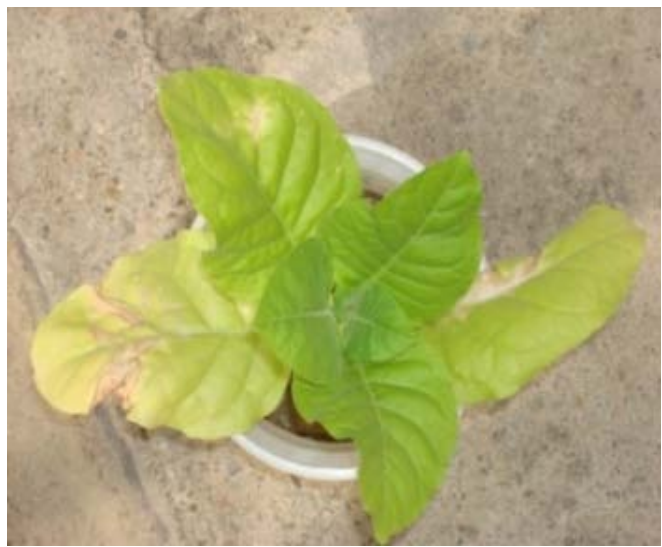

Fig. 7: Symptoms of IYSV in N. Benthamiana: Chlorosis and systemic necrosis

greenhouse at a temperature of $22-25^{\circ} \mathrm{C}$ and were inspected regularly for symptom development. On inoculated leaves of onion plants symptoms (chlorotic and necrotic lesions on leaves and especially on scapes) developed within 2 weeks post inoculation. About 3 weeks after inoculation both symptomatic and asymptomatic plants were assayed by DAS-ELISA to confirm IYSV presence and to detect symptomless infections (Table 6 and Fig. 6 and 7).

RNA electrophoresis: Viral RNA extraction from systemically infected nicotine and onion plants were performed. In order to investigate of RNA quality $3 \mu \mathrm{L}$ extracted RNA with $1 \mu \mathrm{L}$ of color buffer were subjected to

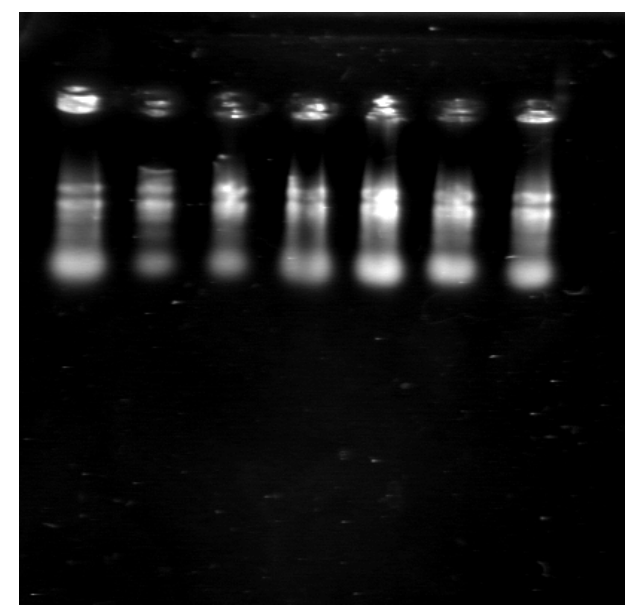

Fig. 8: Analysis of RNA of iris yellow spot virus on $1 \%$ agarose gel

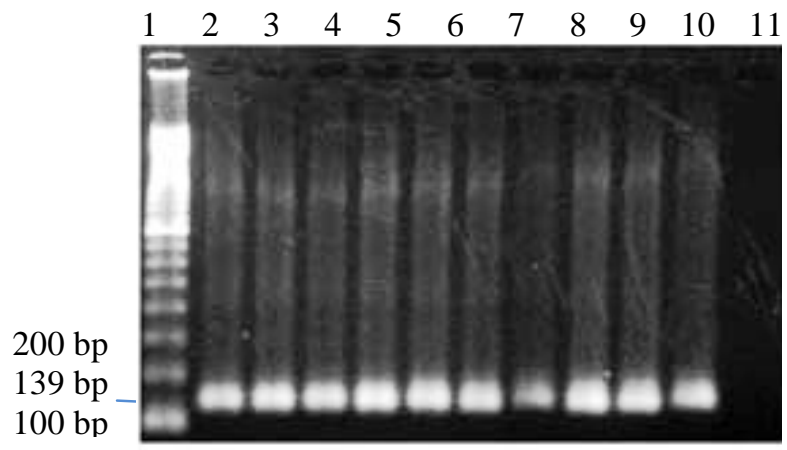

Fig. 9: Results of RT-PCR for sample amplified with promers IYSV-FI/IYSV-RI number is I. ladear

electrophoresis in a $1 \%$ agarose gel, stained with $0.5 \mu \mathrm{g} \mathrm{mL} \mathrm{m}^{-1}$ ethidium bromide and photographed under UV illumination (Fig. 8).

Result of RT-PCR test and diagnose of virus: First strand cDNA was primed on total plant RNA using specific reverse primers using Accupower TMRT Premix kit (Bioneer Company). RT-PCR was carried out with the Accupower TMRT Premix kit (Bioneer Company) according to the manufacturer's instructions. Amplified products were analyzed by $1.7 \%$ agarose gel electrophoresis, stained with ethidium bromide and visualized under a UV transilluminator (Fig. 9). For having high quality Touchdown PCR Method used for delete the additional sections in primer 181 bp (Fig. 10). The primers were able to amplify the amplicon of expected size. RT-PCR with primers IYSV-F1/IYSV-R1, amplified fragments of the expected size (139 bp) from samples infected with IYSV (Fig. 9). Similar results were obtained with primers IYSV-F2/IYSV-R2 that amplified a fragment of 181 bp (Fig. 10). 
Agric. J., 7 (3): 180-186, 2012

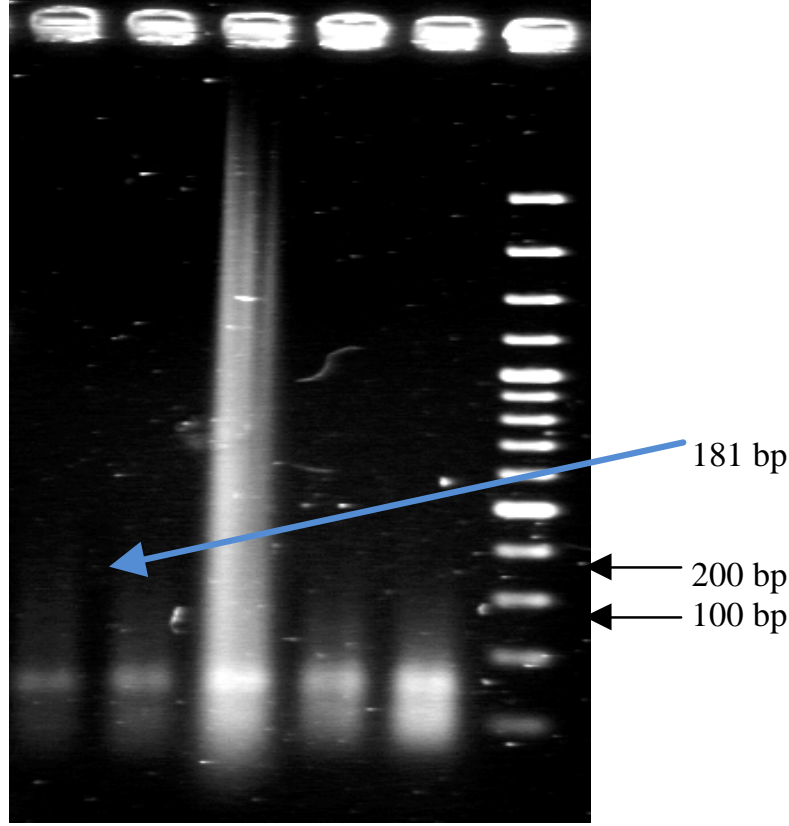

Fig. 10: Results of RT-PCR for sample amplified with promers IYSV-FI/IYSV-RI number is I. ladear

\section{DISCUSSION}

In this study, the molecular and serological studies of the disease were taken placed. Symptoms caused by IYSV in inoculated onion plants in greenhouse (chlorotic and necrotic lesions on leaves and especially on scapes) were very similar to those reported by Mohan and Wilson (1989). This study confirmed that mechanical transmission of IYSV from infected onion samples naturally is possible. Sometime this virus caused symptomless infection of $N$. benthamiana, $N$. clevelandii, $N$. tabacum var. samson and onion plants while IYSV always caused symptomic infection (local lesions) of N. tabacum. Symptoms caused by IYSV in N. rustica (leaf deformation and systemic chlorosis and necrosis) were very similar to those reported by Pozzer et al. (1999). Symptoms caused by IYSV in $N$. clevelandii (systemic chlorose) were similar to those reported by Ravi et al. (2006). N. benthamiana and $N$. clevelandii showed chlorosis and systemic necrosis. N. clevelandii had maximum infection so suggest that use this cultivar in experience methods of this virus in spite of Chatzivassiliou et al. (2000) reported that $N$. benthamiana and $N$. rustica was most important indicator for this virus. Symptom of indicator plants that inoculated with virus and results of DAS-ELISA test and RT-PCR test indicate that infection of IYSV is becoming an increasingly important constraint to onion production. Rapid and accurate diagnostic tools and methods are essential to better understand the epidemiology of the virus and to devise effective management strategies. Standard RT-PCR was more sensitive and rapid than DAS-ELISA. Comparison of four cultivar of onion virus transmission in greenhouse showed that a maximum rate of transmission achieved in red of Dorche Isfahan and minimum rate of transmission achieved in white of Neishabour, so researchers suggest cultivate this genotype. Researchers suggest do more experiment for diagnose of resistant cultivar of onion, diagnose of ornamental hosts, trips and herbs that can transmit virus for provide control methods. Also, researchers suggest do more experiments for diagnose of other hosts of virus among of ornamental plants, crop plants and herbal plants.

\section{ACKNOWLEDGEMENTS}

Researchers thank Assist. Prof. Dr., from the Department of Plant Pathology, Faculty of Agriculture, Ferdowsi University of Mashhad (Iran). Researchers thank for editing the manuscript.

\section{REFERENCES}

Bulajic, A., I. Djekic, J. Jovic, S. Krnjajic, A. Vucurovic and B. Krstic, 2009. Incidence and distribution of iris yellow spot virus on onion in serbia. Plant Dis., 93: 976-982.

Chatzivassiliou, E.K., I. Livieratos, G. Jenser and N.I. Katis, 2000. Ornamental plants and thrips populations associated with tomato spotted wilt virus in Greece. Phytoparasitica, 28: 257-264.

Clark, M.F. and A.N. Adams, 1977. Characteristics of the microplate method of enzyme-linked immunosorbent assay for the detection of plant viruses. J. Gen. Virol., 34: 475-483.

Cortez, I., I.C. Livieratos, A. Derks, D. Peters and R. Kormelink, 1998. Molecular and serological characterization of iris yellow spot virus, a new and distinct tospovirus species. Phytopathology, 88: 1276-1282.

Crowe, F.J. and H.R. Pappu, 2005. Iris yellow spot virus. Plant Dis., 89: 105-105.

Evans, C.K., S. Bag, E. Frank, J.R. Reeve, C. Ransom, D. Drost and H.R. Pappu, 2009. Natural infection of Iris yellow spot virus in Twoscale saltbush (Atriplex micrantha) growing in Utah. Plant Dis., 93: $430-430$.

Gawande, S.J., A. Khar and K.E. Lawande, 2010. First Report of Iris yellow spot virus on garlic in India. Plant Dis., 94: 1066-1066. 
Gent, D.H., L.J. Du Toit, S.F. Fichtner, S.K. Mohan, H.R. Pappu, and H.F. Schwartz, 2006. Iris yellow spot virus: An emerging threat to onion bulb and seed production. Plant Dis., 90: 1468-1480.

Gera, A., J. Cohen, R. Salomon and B. Raccah, 1998. Iris yellow spot tospovirus detected in onion (Allium cepa) in Israel. Plant Dis., 82: 127-127.

Ghotbi, T., N. Shahraeen and S. Winter, 2005. Occurrence of tospoviruses in ornamental and weed species in Markazi and Tehran provinces in Iran. Plant Dis., 89: 425-429.

Hsu, C.L., C.A. Hoepting, M. Fuchs, A.M. Shelton and B.A. Nault, 2010. Temporal dynamics of iris yellow spot virus and its vector, Thrips tabaci (Thysanoptera: Thripidae), in seeded and transplanted onion fields. Environ. Entomol., 39: $266-277$.

Kritzman, A., H. Beckelman, S. Alexandrov, J. Cohen and M. Lampel et al., 2000. Lisianthus leaf necrosis: A new disease of lisianthus caused by Iris yellow spot virus. Plant Dis., 84: 1185-1189.

Mandal, B., H.R. Pappu and A.K. Culbreath, 2001 . Factors affecting mechanical transmission of Tomato spotted wilt virus to peanut (Arachis hypogaea). Plant Dis., 85: 1259-1263.

Mohan, S.K. and D.O. Wilson, Jr., 1989. Scape blight of onion. Proceedings of the National Onion Research Conference, August 16-18, 1989, Boise, ID., USA., pp: 103-104.

Mumford, R.A., R. Glover, M. Daly, T. Nixon, V. Harju and A. Skelton, 2008. Iris Yellow Spot Virus (IYSV) infecting Lisianthus (Eustoma grandiflorum) in the UK: First finding and detection by real-time PCR. Plant pathol., 57: 768-768.
Pappu, H.R., I.M. Rosales and K.L. Druffel, 2008. Serological and molecular assays for rapid and sensitive detection of Iris yellow spot virus infection of bulb and seed onion crops. Plant Dis., 92: 588-594.

Pourian, H.R., M. Mirab-balou, M. Alizadeh and S. Orosz, 2009. Study on biology of onion thrips, Thrips tabaci (Thysanoptera, Thripiddae) on cucumber (var. sultan) in laboratory conditions. J. Plant Prot. Res., 49: 390-394.

Pozzer, L., T. Nagata, M.I. Lima, E.W. Kitajima, R. de O. Resende, and A.C. de Avila, 1994. "Sapeca": An onion disease in Sub-Medio Sao Francisco region, Brazil, is caused by a tospovirus with a serologically distinct nucleocapsid protein. Fitopatol. Bras, 19: 321-321.

Pozzer, L., I.C. Bezerra, R. Kormelink, M. Prins, D. Peters, R.O. de Resende and A.C. de Avila, 1999. Characterization of a tospovirus isolate of Iris yellow spot virus associated with adisease in onion fields in Brazil. Plant Dis., 83: 345-350.

Silva, M.S., C.R. Martins, I.C. Bezerra, T. Nagata, A.C. de Avila and R.O. Resende, 2001. Sequence diversity of NS(M) movement protein of tospoviruses. Arch. Virol., 146: 1267-1281.

Smith, T.N., S.J. Wylie, B.A. Coutts and R.A.C. Jones, 2006. Localized distribution of Iris yellow spot virus within leeks and its reliable large-scale detection. Plant Dis., 90: 729-733.

Ward, L.I., Z. Perez-Egusquiza, J.D. Fletcher, F.M. OchoaCorona and J.Z. Tang et al., 2008. First report of Iris yellow spot virus on Allium cepa in New Zealand. Plant Pathol., 52: 406-406. 